\title{
Magnetofection In Vivo by Nanomagnetic Carriers Systemically Administered into the Bloodstream
}

\author{
Artem A. Sizikov ${ }^{1}$, Petr I. Nikitin ${ }^{2,3, *(D)}$ and Maxim P. Nikitin $1,4, *$ \\ 1 Moscow Institute of Physics and Technology, 141701 Dolgoprudny, Russia; aasizikov88@gmail.com \\ 2 Prokhorov General Physics Institute of the Russian Academy of Sciences, 117942 Moscow, Russia \\ 3 National Research Nuclear University "MEPhI", 115409 Moscow, Russia \\ 4 Department of Nanobiomedicine, Sirius University of Science and Technology, 354340 Sochi, Russia \\ * Correspondence: petr.nikitin@nsc.gpi.ru (P.I.N.); max.nikitin@phystech.edu (M.P.N.)
}

Citation: Sizikov, A.A.; Nikitin, P.I.; Nikitin, M.P. Magnetofection In Vivo by Nanomagnetic Carriers

Systemically Administered into the Bloodstream. Pharmaceutics 2021, 13, 1927. https://doi.org/10.3390/ pharmaceutics 13111927

Academic Editors: Marina Santiago Franco and Yu Seok Youn

Received: 18 October 2021

Accepted: 10 November 2021

Published: 14 November 2021

Publisher's Note: MDPI stays neutral with regard to jurisdictional claims in published maps and institutional affiliations.

Copyright: (c) 2021 by the authors. Licensee MDPI, Basel, Switzerland. This article is an open access article distributed under the terms and conditions of the Creative Commons Attribution (CC BY) license (https:/ / creativecommons.org/licenses/by/ $4.0 /)$.

\begin{abstract}
Nanoparticle-based technologies are rapidly expanding into many areas of biomedicine and molecular science. The unique ability of magnetic nanoparticles to respond to the magnetic field makes them especially attractive for a number of in vivo applications including magnetofection. The magnetofection principle consists of the accumulation and retention of magnetic nanoparticles carrying nucleic acids in the area of magnetic field application. The method is highly promising as a clinically efficient tool for gene delivery in vivo. However, the data on in vivo magnetofection are often only descriptive or poorly studied, insufficiently systematized, and sometimes even contradictory. Therefore, the aim of the review was to systematize and analyze the data that influence the in vivo magnetofection processes after the systemic injection of magnetic nanostructures. The main emphasis is placed on the structure and coating of the nanomagnetic vectors. The present problems and future trends of the method development are also considered.
\end{abstract}

Keywords: magnetofection in vivo; magnetic nanoparticles; iron oxide; gene delivery; gene vectors

\section{Introduction}

The development of nanosystems that effectively deliver genes into a cell in vivo using magnetofection is a complex and urgent task. A solution to this problem will lead to a significant progress in the creation of drug formulations for gene therapy. In such kind of therapy, nucleic acid molecules delivered into a cell can be used for over-expression of a desired protein, for gene knock down effects, for bypassing or even reparation of genetic mutations, or for activation of the innate immune system [1,2]. There are two main factors limiting biomedical applications of the technology. The first one is not fully understood the process of nucleic acids uptake, their intracellular interactions, intracellular trafficking and regulation of nucleic acid action inside cells at the molecular level. The second one is the direct delivery of nucleic acids to target cells [1,3]. Therefore, choice of the reliable and efficient delivery vectors is very important. When we talk about nonviral vectors, magnetic nanoparticles (MNPs) are often meant. They are considered to be in the center of nanotechnology-based structures for nanomedicine [4,5]. Due to their ability to respond to the magnetic field, MNPs have become very attractive for different theranostic applications [6-8]. When using MNPs, it becomes possible to carry out the magnetically controlled accumulation and release of these particles [9-11], execute the particle tracking by magnetic resonance imaging (MRI) [12-14], imaging of tumors [15,16], precise and quantitative monitoring in vitro [17-19] and in vivo [20,21], by the magnetic particle quantification (MPQ) technique in an extraordinarily wide linear dynamic range (up 7 orders of magnitude). MNPs themselves can be used for tumor therapy [22,23], for targeted drug delivery to a selected part of the body [22-24], or for the magnetic separation of cells [22], as well as for magnetofection [1,25,26]. Magnetofection is defined as method for nucleic acid delivery under the influence of a magnetic field acting on nucleic acid 
vectors that are associated with magnetic nanoparticles (see scheme in Figure 1) [27,28]. After reaching the cell surface, magnetic nanosystems (usually with polyethylenimine and DNA) are internalized into intracellular vesicles called endosomes as a result of endocytosis. Moreover, for the functional delivery of nucleic acids, so-called endosome escape is required. Otherwise, the magnetic nanoconstructions will be destroyed by the cellular enzyme system. It is believed that PEI-DNA complexes escape from the endosomes due to the so-called proton sponge effect [29]. Magnetic lipoplexes behave in a similar manner [30]. As in the case of nonmagnetic PEI polyplexes [31], a three-step behavior is observed. At the first stage, the magnetic lipoplexes attach to the cell surface and slowly penetrate the cell membrane. Most lipoplexes are internalized through endocytosis during this phase. The second stage is characterized by abnormal and limited diffusion within cells. The third stage is active transport along microtubules inside the cell.

Compared to the commonly used lipid or polymer-based transfection vectors, magnetofection has several advantages, such as higher efficiency, shorter delivery time, a possibility of very local delivery [32-34]. All the above-mentioned advantages of the method are especially relevant when performing magnetofection in vivo. There are several reviews in the literature devoted to various aspects related to in vitro $[1,5,27,35-41]$ and in vivo [42] magnetofection. The latter work considers in vivo delivery of genes using magnetic carriers injected locally to targeted tumors or tissues [42]. In the current work, we provide an overview of the published results on the systemic injection of complex magnetic nanostructures into living organisms. The delivery of drugs/genetic information to the close vicinity of the site of action (tumor, target organ, etc.) is considered to be local. The administration into the circulatory system so that the entire body is affected is regarded as systemic. The main focus is on the magnetic vector structure. We discuss in detail different types of coating of various magnetic particles, give several examples of "unusual" magnetic carriers. Special attention is given to possible ways of development of the existing technology, challenges and prospects of the method.

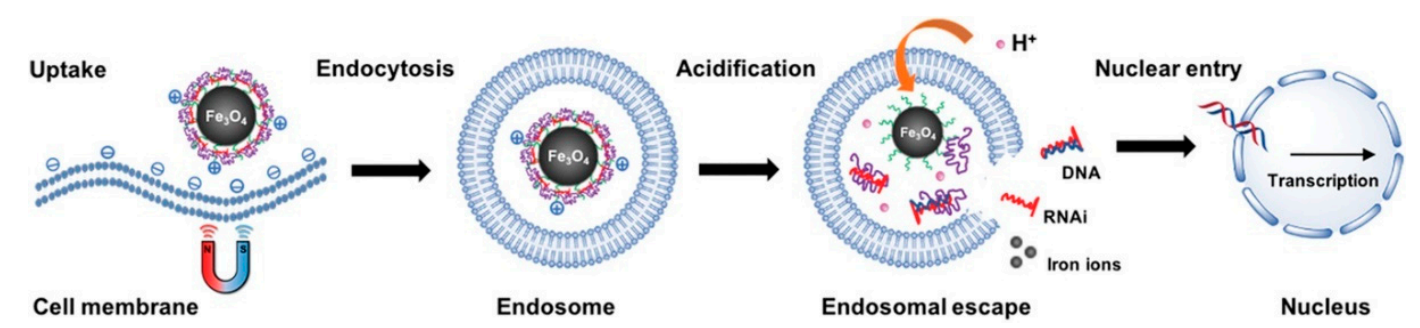

Figure 1. Magnetofection using magnetic nanoparticles. The plasmid DNA is associated with magnetic nanoparticles, which are directed, attracted, and concentrated on the surface of cell membranes, where the endocytosis process brings the nanoparticles into the cell. Adapted with permission from [43].

\section{Applications of Nanoscale Carriers for Magnetofection In Vivo}

This review is a logical continuation of our previous work [42], where examples of in vivo magnetofection were described in detail for the case of administrating the magnetic vectors directly into a targeted tumor or tissue. Local injections actually allow to avoid such negative effects as undesired interactions with blood components and rapid elimination from the circulation by the reticuloendothelial system (RES). The aim of the present review is to collect and analyze data that influence the processes of magnetofection in vivo after systemic injections of the nucleic acid-bearing magnetic nanoparticles. We have summarized the related results available in various publications on the topic in Table 1. 
Table 1. Typical targets, nucleic acid types, magnetic nanoparticle compositions used in published research on magnetofection in different animals after systemic injections of magnetic carriers.

\begin{tabular}{|c|c|c|c|c|}
\hline Target (Tissue/Organ) & Animals & Nucleic Acid Type ${ }^{\text {a }}$ & $\begin{array}{l}\text { Magnetic Nanoparticle } \\
\text { Composition }\end{array}$ & References \\
\hline Subcutaneous tumor/heart & Mouse & shRNA & combiMAG + Lp2000 & [44-46] \\
\hline Subcutaneous tumor & Mouse & pDNA & $\mathrm{Fe}_{3} \mathrm{O}_{4} @ \mathrm{SiO}_{2}-\mathrm{COOH}+\mathrm{PEI}$ & [47] \\
\hline Lungs/heart & Mouse & pDNA & MNBs (Miltenyi Biotec)-PEI & [48] \\
\hline $\begin{array}{l}\text { Right proximal region } \\
\text { (subcutaneous tumor) }\end{array}$ & Mouse & siRNA & LipoMag & [10] \\
\hline Right testis & Mouse & Antisense ODN & PolyMag & [49] \\
\hline Liver & Rat & pDNA & MCL & [50] \\
\hline Hind leg & Mouse & pDNA & $\mathrm{PAAIO}+\mathrm{CP}$ & {$[51]$} \\
\hline Striatum & Mouse & siRNA & Tf-PEG-PLL/MNP & [52] \\
\hline Subcutaneous tumor/armpit & Mouse & siRNA & $\mathrm{Fe}_{3} \mathrm{O}_{4}+$ Chitosan & {$[53]$} \\
\hline dorsal flank (subcutaneous tumor) & Mouse & pDNA & M-MSNs & [54] \\
\hline $\begin{array}{l}\text { Capsule of the liver lobe } \\
\text { (transplanted tumor) }\end{array}$ & Mouse & pDNA & Gal-CMCS- $\mathrm{Fe}_{3} \mathrm{O}_{4}-\mathrm{NPs}$ & [55] \\
\hline Left hepatic lobe & Mouse & siRNA & Gal-PEI-SPIO & [56] \\
\hline Heart & Mouse & pDNA & $\mathrm{MNB} / \mathrm{PEI}$ & [57] \\
\hline Subcutaneous tumor & Mouse & pDNA & TSMCL & [58] \\
\hline Vessels of the dorsal skin & Mouse & pDNA & MMB & [59] \\
\hline
\end{tabular}

${ }^{a}$ pDNA = plasmid DNA, Antisense ODN $=$ antisense oligonucleotide, siRNA = small interfering $\mathrm{RNA}^{\mathrm{b}}$ combiMAG $=$ commercial magnetofection reagent, Lp2000 $=$ Lipofectamine ${ }^{\circledR} 2000$ - commercial transfection reagent, $\mathrm{PEI}=$ polyethylenimine, $\mathrm{MNB}=$ magnetic nanobeads (MiltenyiBiotec, Auburn, CA, USA), LipoMag=commercial transfection kit, PolyMag (Chemicell, Berlin, Germany) = commercial iron oxide nanoparticles, $\mathrm{MCL}=$ magnetic cationic liposome, $\mathrm{PAAIO}=$ poly (acrylic acid) - bound superparamagnetic iron oxide, $\mathrm{CP}=$ polyethylenimine copolymer, $\mathrm{Tf}=$ transferrin, $\mathrm{PEG}=$ polyethylene glycol, $\mathrm{PLL}=$ poly-L-lysine, $\mathrm{MNP}=$ magnetic nanoparticle, $\mathrm{M}-\mathrm{MSNs}$ = magnetic mesoporous silica nanoparticles, $\mathrm{Gal}=$ galactose, $\mathrm{CMCS}=$ carboxymethyl chitosan, $\mathrm{NPs}=$ nanoparticles, $\mathrm{SPIO}=$ superparamagnetic iron oxide, TSMCL = magnetic 1,2-dipalmitoyl-sn-glycero-3-phosphocholine (DPPC), 3b-[N-(N',N'-dimethylaminoethane)-carbamoyl]cholesterol (DC-Cholesterol), dimethyldioctadecylammonium bromide (DOAB) and cholesterol liposomes at a molar ratio of 80:5:5:10, $\mathrm{MMB}=$ micromagnetobubbles.

The efficiency of the in vivo application of one more magnetic nanocarriers critically depends on the charge and type of the magnetic core coating. Therefore, in this section, we have divided the data into three subsections: magnetic polyplexes (magnetic nanoparticles coated with cationic polymers, Figure 2a), magnetic liposomes (lipid-coated magnetic nanoparticles, Figure $2 b$ ), and magnetic nanosystems with an additional active targeting modality (along with the response to the magnetic field, Figure 2c). Furthermore, possible ways of the method evolution are discussed in detail.

\subsection{Magnetic Nanoparticles Coated with Cationic Polymers}

After the development of a method to synthesize a low aggregated magnetic polyethyleneimine/DNA nanostructures (MPD) and testing these particles when injected locally into a tumor [60], the same authors continued their research on the efficient transfection activity in a serum-containing medium and MPD application in vivo after intravenous injections [47]. The magnetic vector synthesis is described in [60]. Shortly, MNPs were synthesized by two different methods in aqueous [61] and organic media [62] with subsequent modification by ligand exchange or by silane-coupling agents to prepare a negatively charged coating. For this purpose, $\mathrm{N}$-(trimethoxysilylpropyl) ethylenediaminetriacetic acid was used. As a result, the luciferase gene expression in tumors substantially differed for the traditional transfection and magnetofection groups. The luciferase activity effected by the transfection with MPD nanostructures subjected to a magnetic field was about five times stronger compared to that obtained without field application or by the control standard 
PEI-DNA complexes. It is also worth noting that a large portion of the particles in all cases settled in the animal's lungs.

a

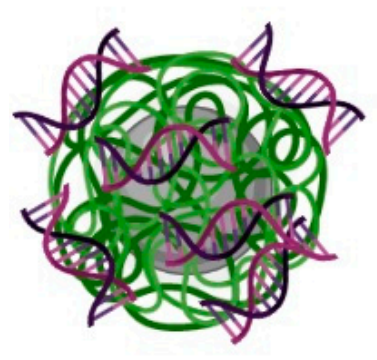

b
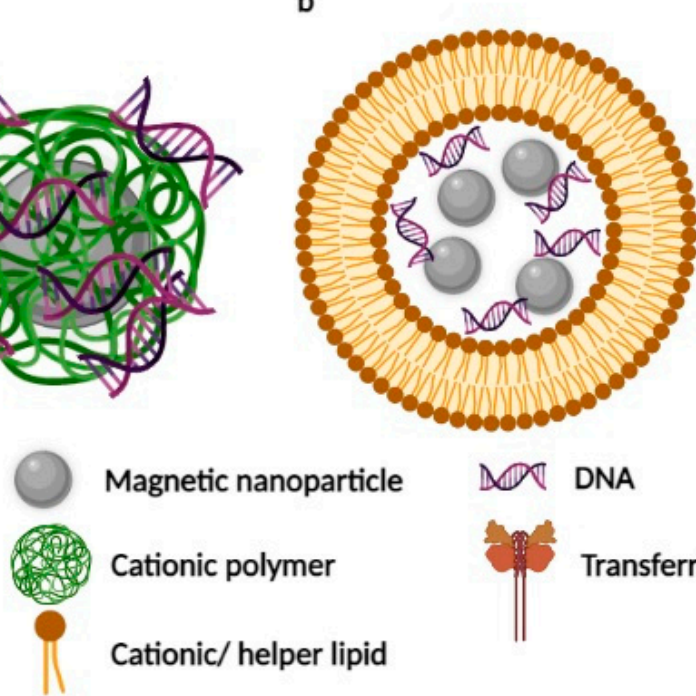

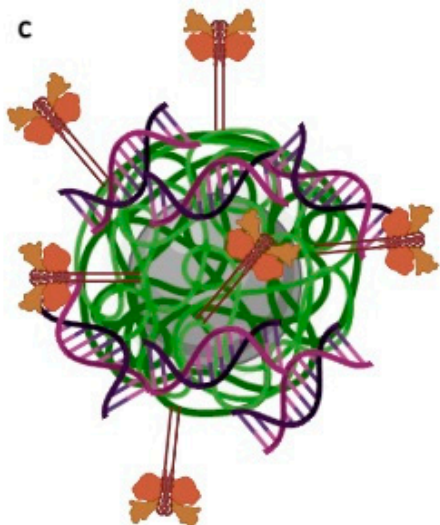

Transferrin

Figure 2. Schematic examples of different magnetic nanocarriers for magnetofection in vivo: (a) magnetic polyplex, (b) magnetic liposome, (c) magnetic polyplex modified with transferrin. Created with BioRender.com (accessed on 7 November 2021).

In contrast, an even higher luciferase activity was recorded, when commercial magnetic nanoparticles were used, namely MNBs (MiltenyiBiotec, Auburn, CA, USA) with an average size of $200 \mathrm{~nm}$ [48]. The magnetic polyplex was prepared as follows: biotinylated PEI/DNA complexes were conjugated to MNBs via a sulfo-NHS LC-biotin linker. Two hours after systemic administration of the labeled MNB/Oregon green 488$\mathrm{PEI} / \mathrm{pREP}$ /Luc nanostructures, their accumulation was assessed in vivo by a bioimaging system that detected fluorescence. When using a magnet, the intensity was about 18 times higher in the left side of the animal's chest than without the magnetic field (Figure 3), indicating that the magnet effectively attracted the nanostructures to the left chest (heart and left lung).

Additionally, the magnetic field application caused strong therapeutic gene expression in the left lung and heart. Unfortunately, there was no quantitative assessment as in another publication with similar particles [57], where the level of luciferase gene expression in the heart increased more than three orders of magnitude (!) compared with the control mice without implantation of an epicardial magnet. Another example of work using magnetic vectors based on commercial nanoparticles is discussed in [49]. To investigate whether magnetofection could be a feasible strategy for directing antisense ODN to one specific vascular site after an intra-arterial injection in vivo, the authors infused mice with Cy3-labeled antisense ODN complexed to PolyMAG magnetic particles through a femoral catheter. As a result, solely all large and small arterioles of the cremaster muscle exposed to the magnetic field after the injection of the ODN-MP mixture showed a high level of fluorescence. That was not the case in the vessels of the cremaster muscle of the contralateral testis in the same animals. In these control vessels, similar to the control animal, which was injected with a magnetic vector without applying a magnetic field, only a few large arterioles and none of the small arterioles showed fluorescence, which qualitatively indicated that magnetofection is a working method for active targeting. 


\section{A}
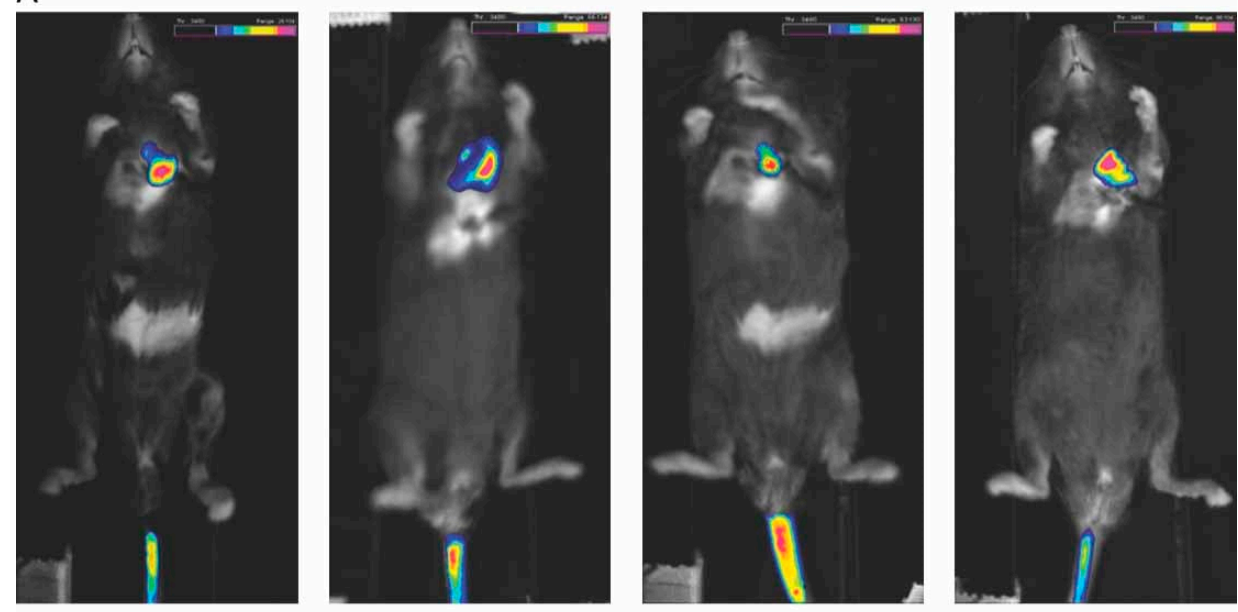

B
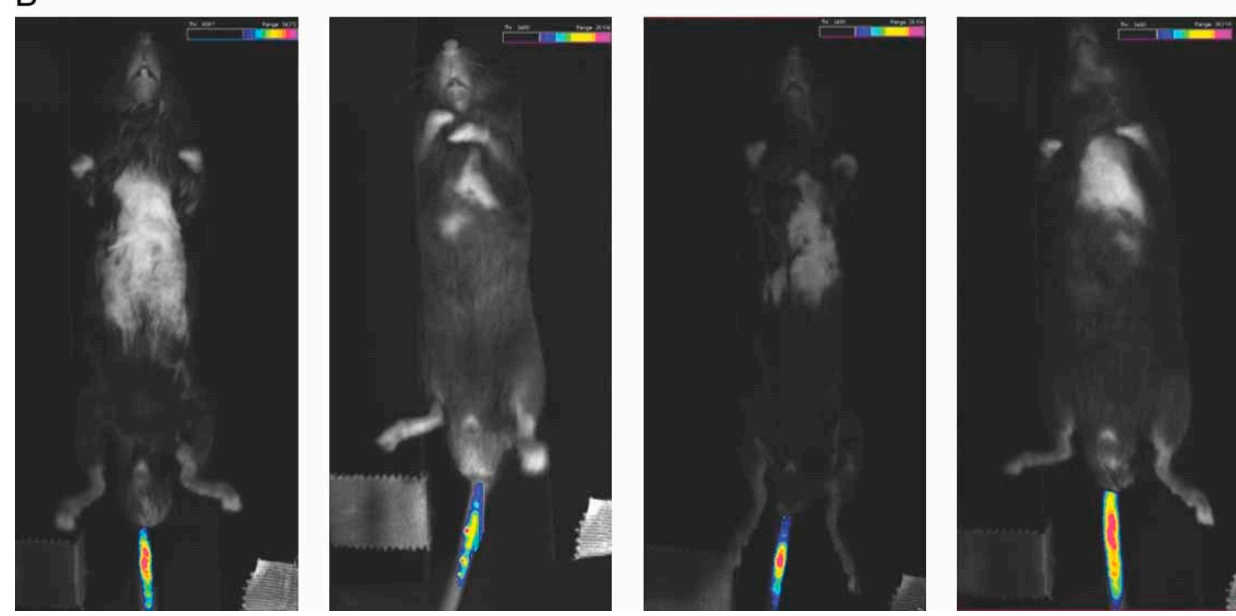

Figure 3. Non-invasive in vivo trafficking of MNB/PEI/DNA nanostructures $2 \mathrm{~h}$ after systemic administration. The fluorescent image (pseudocolor) was overlaid on the photographic image. The intensity of fluorescent signal from MNB/Oregon green 488 labeled-PEI/DNA was stronger in the left chest in group with magnet (A) compared to the group without magnet (B). Adapted with permission from [48].

The work of [53] aimed at estimating the targeting capacity in vivo under the influence of a magnetic field of angiopoietin-2 small-interfering RNA (Ang-2 siRNA) plasmid/chitosancoated magnetic nanoparticles in a model of malignant melanoma (MM) in nude mice. The method of obtaining chitosan magnetic nanoparticles was quite interesting. At the first stage, magnetic $\mathrm{Fe}_{3} \mathrm{O}_{4}$ nanoparticles were dispersed in a chitosan solution (Zhejiang Hisun Chemical Co., Ltd., Taizhou, China) under ultrasound agitation. Subsequently, the mixture was added to a mixed phase solvent of liquid paraffin and petroleum ether supplemented with Span-80. The solution was sufficiently emulsified and agitated, then glutaraldehyde solution was slowly added dropwise. Then, the solution was incubated at $40{ }^{\circ} \mathrm{C}$ in a water bath for 30 min followed by adjustment $\mathrm{pH}$ to 9.0 with $\mathrm{NaOH}$ solution. The resulting solution was heated to $60^{\circ} \mathrm{C}$. After standing for $1 \mathrm{~h}$, the precipitate was produced. Then, successive thorough washings with anhydrous ether, acetone, anhydrous ethanol, and distilled water produced the chitosan magnetic nanoparticles. As a result, it was shown, at a qualitative level, that the targeting group (particles + magnetic field) exhibited aggregation of numerous particles on the capsule of tumor tissues and inside blood vessels and staining with Prussian blue was strictly positive.

Another example of using custom-made magnetic particles is given in [51]. It was proposed to use chondroitin sulfate-polyethylenimine copolymer (CP)-coated superparamag- 
netic iron oxide nanoparticles as an efficient magneto-gene carrier for microRNA-encoding plasmid DNA delivery. The magnetofection gene carrier was prepared by complexation through electrostatic interactions between CP and self-made [63] poly(acrylic acid)-bound iron oxide nanoparticles (SPIONs) (named CPIO). To evaluate the in vivo magneto-induced uptake of the magnetoplex, a biodistribution of CPIO/Cy5-DNA was studied in nude mice with U87-xenografted tumors on the right and left hind leg regions. As a result, the enhanced permeability and retention (EPR) effect [64] played a greater role in biodistribution than the magnetic field (after $48 \mathrm{~h}$, both tumors glowed, the one above, where the magnet was located, glowed slightly stronger).

Magnetic mesoporous silica nanoparticles (M-MSN) are an unusual example of a magnetic vector for in vivo magnetofection. The research of [54] aimed at creating M-MSNs that differed in shape followed by a comparative study of their efficiency in suicide gene therapy of hepatocellular carcinoma (HCC). As a model, the thymidine kinase/ganciclovir of herpes simplex virus (HSV-TK/GCV) gene therapy system was used. Carboxyl-functionalized M-MSNs were first loaded with GCV. Then, PEG-g-PLL was introduced to ensure a positive surface charge of the resulting nanostructure for electrostatic absorption of the TK plasmid. At the first stage, nanosized magnetite coated with polyacrylic acid was obtained [65]. Then, spherical (S-M-MSNs) and rod-shaped (R-M-MSNs) mesoporous silica nanoparticles were synthesized by a simple sol-gel method using the obtained $\mathrm{Fe}_{3} \mathrm{O}_{4} \mathrm{NPs}_{\text {and }}$ cetyltrimethylammonium bromide (CTAB) as a template [66,67]. After that, carboxylatemodified M-MSNs were formed via reactions of M-MSNs with ammonium persulfate (APS) and further with succinic anhydride [68,69]. Finally, PEG-g-PLL and M-MSNs-COOH were covalently conjugated using a modified EDC/NHS reaction according to [70,71]. To evaluate the therapy results, the authors proposed a comparison of the sizes of the respective tumors. Compared to the control group, which was given only saline, tumor growth inhibition was observed in all other cases. In addition, the group that was treated with the magnetic field showed a significant reduction in the relative tumor volume and weight compared to the non-magnetic group. Moreover, if both types of the field (constant and variable) were used, then the tumor was less than under a single field type, while the latter, in turn, was less than without any field.

\subsection{Lipid-Coated Magnetic Nanostructures}

The use of magnetic lipoplexes via magnetic field-assisted systemic delivery appeared to be a much more popular method compared to the local delivery [42]. A team of authors led by Aiqiang Dong believes that liposomal magnetofection works best when administered systemically and that the magnetic field potentiates gene transfection to concentrate magnetic lipoplexes onto target cells [44-46]. In all three papers, the magnetic nanosystems had the following composition: pGFPshIGF-1Rs/combiMAG/lp2000. In [44], it was shown that the silencing efficiency of shRNAs delivered by the liposomal magnetofection after a pGFPshIGF-1R injection reached $43.4 \pm 5.7 \%, 56.3 \pm 9.6 \%$, and $72.2 \pm 6.8 \%$ at 24,48 and $72 \mathrm{~h}$, respectively, and reached an average of $43.8 \pm 5.3 \%$ by lipofection. The biological distribution and target tumor suppression after magnetofection were also studied along with the potential toxicity of the method via combiMAG-carrying plasmids expressing green fluorescent protein (GFP) and short hairpin RNAs (shRNAs) targeting IGF-1R (pGFPshIGF-1Rs) in tumor-bearing mice [45]. In that work, the accumulation and delivery of pGFPshIGF-1R into tumors using magnetic nanoparticles and a magnetic field contributed to a significant decrease in tumor growth compared to the control, the suppression rate was $36 \%$ on day 30 after treatment. The same magnetic lipoplex can be used for gene therapy after heart failure [46]. The results showed that the silencing efficiency of shRNAs delivered by liposomal magnetofection reached 72.2 $\pm 6.8,80.7 \pm 9.6$ and $84.5 \pm 5.6 \%$, at 24,48 and $72 \mathrm{~h}$, respectively, after pGFPshIGF1R injection.

Namiki Y. et al. [10] described the development of a new nanoparticle, which consisted of an oleic acid-coated magnetic nanocrystal core and a cationic lipid shell (DOTAP ( $N$-[1-(2,3-dioleoyloxy) propyl]- $N, N, N$-trimethylammonium chloride) and DOPE (dioleoylphos- 
phatidylethanolamine) (1:1)). The lipid mixture dissolved in chloroform was mixed with chloroform-based magnetic fluid. After the addition of distilled water, the homogeneous mixture was evaporated, sonicated, and purified, finally forming LipoMag. LipoMag/siRNA EGFR\#4-mU (siRNA to efficiently knock down the EGFR mRNA in tumor vessels) treatment under a magnetic field exhibited a $\approx 50 \%$ reduction in the tumor volume compared with the control group on day 28th after the treatment initiation.

It is known that liposomes composed of DC-Chol $\left(3 \beta-\left[N-\left(N^{\prime}, N^{\prime}\right.\right.\right.$-dimethylaminoethane $)$ carbamoyl] cholesterol) and DOPE (Dioleoylphosphatidylethanolamine) have been classified as one of the most efficient vectors for transfection of pDNA into cells and in clinical trials [72-74]. In the work [50], DC-Chol and DOPE (1:1 molar ratio) were chosen as the liposome composition, MAG-T (aqueous dispersion of magnetite $\mathrm{Fe}_{2} \mathrm{O}_{3}$; tartaric acid matrix; mean diameter of $20 \mathrm{~nm}$ ) was used as the core, and the MCLs were prepared using reverse-phase evaporation. Since the target organ was the liver, the observed luciferase activity $24 \mathrm{~h}$ after injection was only one when using MCLs/pDNA nanoformulations under the influence of a magnetic field and 1.5-fold higher compared to the same particles without the field (Figure 4).

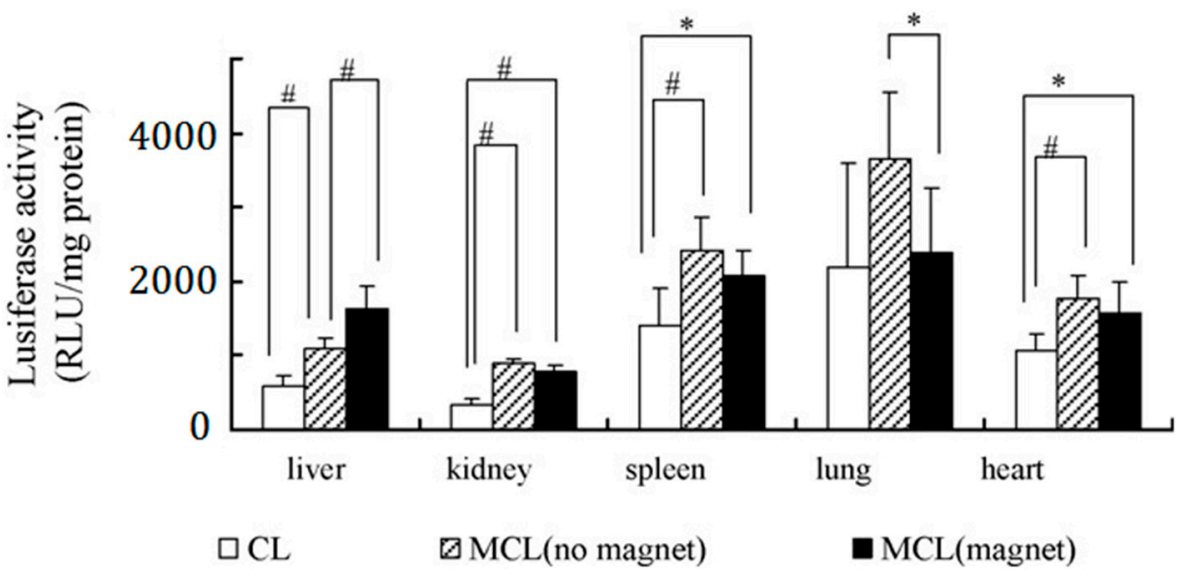

Figure 4. Effect of external magnetic field on the transfection activity of MCLs/pDNA nanoformulations in vivo. The concentration of MAG-T in the MCLs was $1.5 \mathrm{mg} / \mathrm{mL}$ and the weight ratio between MCLs and pDNA was 8.0. Luciferase activity was determined $24 \mathrm{~h}$ post-injection in the liver, kidney, spleen, lung, and heart, respectively. Each value represented mean \pm S.D. $(n=6) .{ }^{*} p<0.05$, $\# p<0.01$. Adapted with permission from [50].

Another interesting example employing magnetic liposomes is presented in [58]. Here, the delivery system was based on thermosensitive cationic liposomes, which were prepared with a thermosensitive cationic formulation of 1,2-dipalmitoyl-sn-glycero-3phosphocholine (DPPC), 3b-[N-( $N^{\prime}, N^{\prime}$-dimethylaminoethane)-carbamoyl]cholesterol (DCCholesterol), dimethyldioctadecylammonium bromide (DOAB) and cholesterol at a molar ratio of 80:5:5:10 (TSCL liposomes). To prepare the magnetic liposomes (TSMCL), a magnetic fluid $\mathrm{Fe}_{3} \mathrm{O}_{4}$ was used as the core, which was co-encapsulated with ammonium sulfate buffer into the liposomes. The authors of the study [58] designed TSMCL-DOX-shSATB1 as a combined magnetic drug targeting and a magnetofection system to improve the efficiency of simultaneous delivery of DOX and SATB1 shRNAs. Co-delivery of DOX and the shSATB1 vector in an in vivo mouse xenograft model under the influence of a magnetic field resulted in weaker tumor growth compared to control mice.

After studying the behavior of micromagnetobubbles (MMB) through a local injection [75], the same authors continued their research trying systemic administration [59]. The endothelium of the treated dorsal skin clearly showed expression of the dsRed protein 48-72 h after treatment. That expression could not be observed in the vessel wall of mice treated with the plasmid-loaded MMB, where no external magnetic field and ultrasound had been applied, or in the equally treated mice, where only a magnetic field was applied but no ultrasound. Interestingly, although mice treated with only ultrasound but without a 
magnetic field showed low rates of transfection into the vascular wall in vivo, this effect was more than 60 -fold lower than that observed when a magnetic field was added to retain the MMB at the vascular wall.

\subsection{Magnetic Nanosystems Possessing an Additional Active Targeting Modality}

In order to enhance the penetration of small interference RNA against the pololike kinase I (siPLK1) across the blood-brain barrier to treat glioblastoma (GBM), magnetic nanoparticles (Tf-PEG-PLL/MNP@siPLK1) modified with transferrin (Tf) were prepared [52] and two types of active targeting were applied. Transferrins are iron-binding blood plasma glycoproteins that control the level of free iron (Fe) in biological fluids [76]. MNPs $\left(\mathrm{Fe}_{3} \mathrm{O}_{4}\right)$ were prepared by alkaline co-precipitation [77] with subsequent linking with Tf-PEG-PLL or PEG-PLL. When evaluating in vivo anti-GBM activity, it was found that the tumor inhibition rate raised with increasing the dosage of the magnetic nanocarrier with trans-peptide (no-field conditions were not considered). The biodistributions of another self-luminous siRNA with and without application of the magnetic field were also evaluated (Figure 5).

The fluorescence intensity was significantly higher in the brain upon administration of Tf-PEG-PLL/MNP@Cy5-siPLK1 compared to PEG-PLL/MNP@Cy5-siPLK1 without transferrin. Moreover, it turned out that the magnetic field significantly increased the accumulation of Cy5-siPLK1 in the brain tissues. That, in turn, might contribute to the high activity of Tf-PEG-PLL/MNP @ siPLK1 in vivo against GBM.

The authors of Ref. [55] developed a nanovector with double targeting properties for the efficient delivery of a tumor suppressor gene RASSF1A specifically into hepatocellular carcinoma (HCC) cells by preparing galactosylated-carboxymethyl chitosanmagnetic iron oxide nanoparticles (Gal-CMCS-Fe ${ }_{3} \mathrm{O}_{4}-\mathrm{NPs}$ ). It is known that galactose (Gal)-modified magnetic nanoparticles can be discerned specifically by the asialoglycoprotein receptor expressed on the surface of HCC cells and specifically recognized by HCC cells [78]. $\mathrm{Fe}_{3} \mathrm{O}_{4} \mathrm{NPs}$ themselves were obtained in the aforementioned research by alkaline co-precipitation [77], then coated with chitosan [79] followed by the addition of lactose and sodium cyanoborohydride to obtain Gal-CMCS- $\mathrm{Fe}_{3} \mathrm{O}_{4} \mathrm{NPs}$. The authors studied the biodistribution of the particles loaded with pcDNA6.2mir-EGFP using fluorescent microscopy to visualize GFP expression. They noted green fluorescence in liver and tumor tissues. The average efficiency of pcDNA6.2mir-EGFP transfection in liver tissue was 32.6\%. In addition, the average transfection efficiency in tumor tissue was approximately $40.8 \%$ and $29.7 \%$ when using an external magnetic field and without it, respectively. No overt fluorescence was observed in sections of kidney, spleen, heart, or lung tissues. As for delivery of the RASSF1A gene for HCC treatment, the best results were achieved when a combination of the magnetic vector, external magnetic field, and intra-abdominal administration of mitomycin (MMC — chemotherapy drug) were used for treatment.

The authors of [56] considered magnetic vectors, in which the core consisted of iron oxide modified by galactose (Gal) and polyethylenimine (PEI). The latter acted as shells providing targeted delivery of therapeutic siRNA to the liver cancer. Carboxylate-capped $\mathrm{Fe}_{3} \mathrm{O}_{4}$ was initially synthesized via the modified oxidative co-precipitation method [80]. Subsequently, PEI was further attached to the surface of $\mathrm{Fe}_{3} \mathrm{O}_{4}-\mathrm{COOH}$ via 1-ethyl-3-(3dimethylaminopropyl)carbodiimide (EDC) followed by the addition of Gal-PEG-NH2. The biodistribution study of the Gal-PEI-SPIO/Cy5-siRNA particles showed rapid accumulation of Cy5-siRNA in the liver and tumor within $8 \mathrm{~h}$. The fluorescence was much more pronounced compared to the case of nano-encapsulated Cy5-siRNA. Fluorescence from Cy5-siRNA was observed within $24 \mathrm{~h}$ and decayed significantly over time. With Gal-PEI-SPIO nanoparticles coated with Cy5-miRNA, the fluorescence intensity began gradually decreasing only after $8 \mathrm{~h}$ since administration. After $24 \mathrm{~h}$, it was still observable and stronger than that in the control group (RNA only). It was found that the use of a magnetic field did not play a significant role in the inhibition of tumor growth. In general, tumors treated with Gal-PEI-SPIO/si-c-Met showed an obvious decrease in volume. c-Met 
is a hepatocyte growth factor (HGF) receptor that plays an important role in the proliferation, motility, differentiation, and angiogenesis of HCC [81]. As a result, both groups (with and without magnetic field), in which treatment was used with particles with siRNA, which silenced the expression of c-Met, demonstrated a significant (and almost the same) reduction in tumor volume compared to the control group.

A

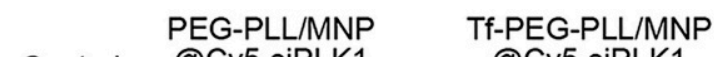
Control @Cy5-siPLK1 @Cy5-siPLK1

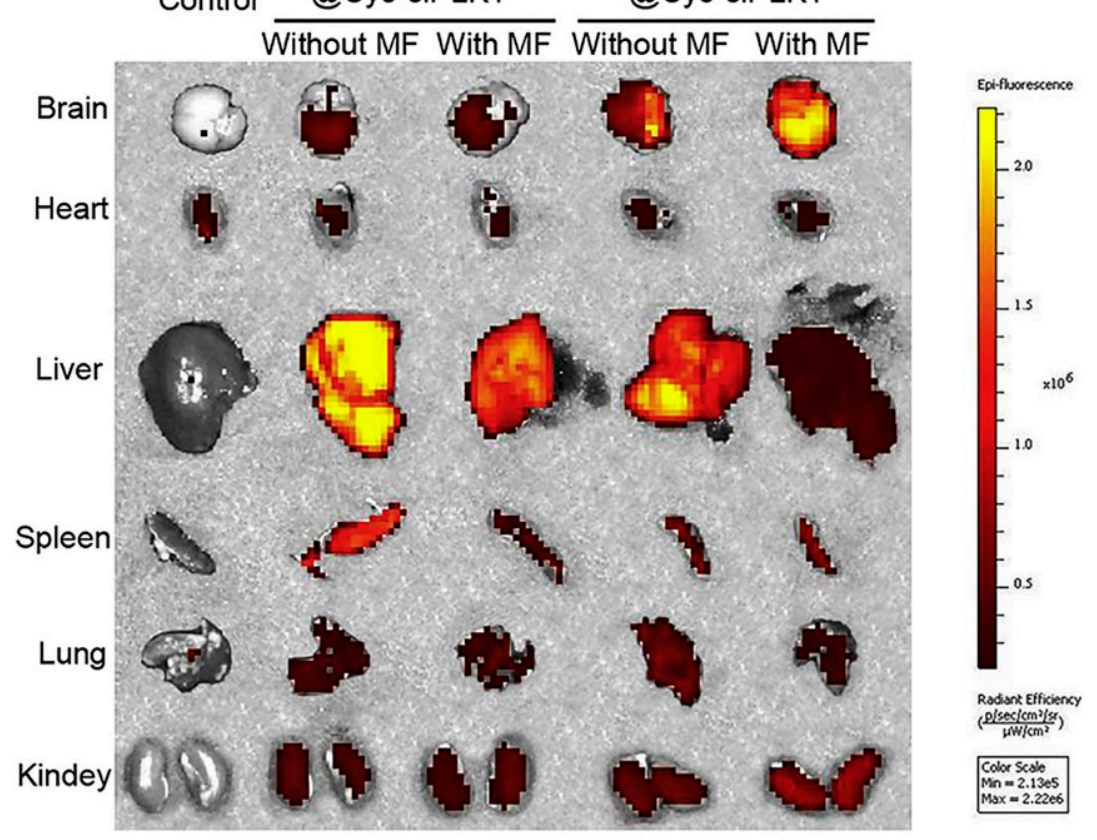

B

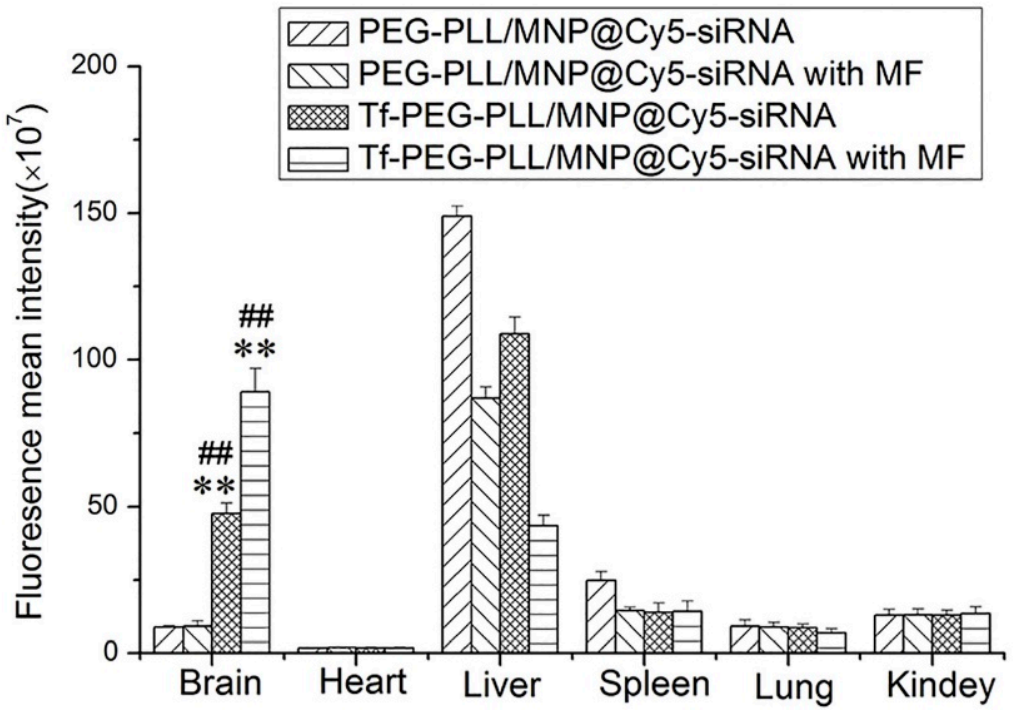

Figure 5. (A) Biodistribution of Cy5-siPLK1 in mice organs at $12 \mathrm{~h}$ after the administration of Tf-PEGPLL/MNP@siPLK1 and PEG-PLL/MNP@siPLK1 by tail vein injection. MF presents the application of magnetic field. (B) The statistic results of panel A. ${ }^{* *} p<0.01$, vs PEG-PLL/MNP@siPLK1 without MF; \#\# $p<0.01$, vs PEG-PLL/MNP@siPLK1 with MF. Data are expressed as the mean $\pm \operatorname{SD}(n=3)$. Adapted with permission from [52].

\section{Conclusions and Outlook}

In this review, we have summarized the results of publications devoted to in vivo magnetofection for the case of systemic injection of magnetic nanocarriers and tried to figure out how it works depending on the structure of these magnetic vectors. Judging from 
the above-cited articles, we can say that the method proved to be a good tool for delivering genetic material (pDNA, siRNA, or antisense ODN, see Table 1) to tumors and tissues via magnetic nanoparticles with various types of coating. Due to the use of a magnetic field, a rather high delivery targeting is achieved at a low loading dose. All this moves magnetofection one step closer to practical applications in gene therapy.

Indeed, it has mentioned in a number of articles that the use of a magnetic field leads to higher gene expression on qualitative $[45,49,51]$ and quantitative $[47,48,50,52,56,57]$ levels. There is also numerical data on a significant decrease in tumor growth compared to control groups $[10,45,52,55,56,58]$, as well as data on silencing efficiency $[44,46]$, which indicate the positive effect of the magnetic field on the transfection process. A logical step would be to compare the results that scientific groups, which study in vivo magnetofection, obtained with the systemic and local routes of injection of magnetic nanostructures based on the same magnetic carriers. This is what the authors of $[47,60]$ carried out. They declared in [47] that transfection by nucleic acid-bearing magnetic nanosystems under a magnetic field produced the highest level of luciferase activity, which was approximately 5-fold higher than that of the magnetic systems without field (when administered locally, the difference was 15-fold [60]). There is also a similar example from a group that has studied the transfection properties of micromagnetobubbles in vivo (local [75] and systemic [59] injections, respectively). Unfortunately, the results of these works could not be directly compared. There are no more examples of such comparisons, probably due to the problems that may be encountered while studying magnetofection in vivo.

The first problem of the precise magnetic guidance of complex magnetic nanostructures is the effect of applied magnetic fields. It is clear that an external magnetic field of higher intensity and gradients contributes to the faster accumulation of the magnetic nanosystems in a target region. On the other hand, an excessively strong magnetic force will result in too intense aggregation of nanoparticles, thus affecting their stability and causing potential cytotoxicity [43]. In turn, a nonlinear decrease in magnetic force with an increasing distance inevitably leads to a weaker response to the external magnetic field, which may become not strong enough to steer the magnetic nanoparticles in the blood flow deep in the body [82]. It would be interesting to study the transgene expression applied with an external magnetic field of stronger gradients, which could penetrate at a larger distance on an intact animal model. In addition, it is difficult, using the current approach, to eliminate completely gene expression in other organs, at least with the commonly used $\mathrm{NdFeB}$ magnets. This emphasizes the need for a more focused magnetic field of a higher gradient as, for example, in magnetic systems based on $\mathrm{NdFeB}$ micromagnets [83]. In particular, it is reported that the magnetic targeting of deeper situated tissues or of structures situated deeper within organs is weakened, and the enhanced permeability and retention effect, in this case, plays a greater role in biodistribution than the gradient magnetic field $[51,84]$. To overcome this problem, one of the approaches is to use field-enhancing elements as noted in [85-88], where vascular stents were made magnetic by nickel coating. If implanting these into a deeper situated vessel, these may influence the original magnetic field when magnetized by an external magnetic field and thus may generate strong field gradients deeper into the tissues. Another example of such an invasive technique is the implantation of ferromagnetic wires and exposure of the target area or the whole patient body to an external magnetic field. In this way, strong magnetic field gradients are produced locally and allow capture and concentration of circulating magnetic nanoparticles $[89,90]$. Alternatively, high gradient [91] or oscillating [92-94] magnetic fields can be used for standard magnetic nanoparticles. Another option is an employment of magnetic materials with higher specific magnetization than iron oxide, but this approach raises biocompatibility concerns. A comparison between magnetite and cobalt nanoparticles (the latter exhibiting a higher magnetization than that of magnetite) of identical sizes and coatings demonstrated similar transfection efficiencies but cobalt cytotoxicity was greater, and the nanoparticles tended to aggregate [38]. For a closer look at modern magnetic systems that allow precise magnetic guiding, we direct the reader to detailed reviews [43,95-97]. 
The second problem is that in order to further improve the binding of ligands to specific cells, it is necessary to introduce functional ligands such as galactose, folic acid, epithelial cell adhesion molecule and $\alpha$-fetoprotein that can actively interact with the corresponding binding sites on the cell surfaces $[48,55,98]$. For example, it is claimed in [48] that conjugation of magnetic nanosystem with a vasculature-permeabilizing agent, such as histamine [99], VEGF [100], or serotonin [101], may further help such complex magnetic nanostructures to cross the endothelial barrier and deliver therapeutic genes to other cell types.

The third problem is that magnetic nanostructures during circulation in the bloodstream inevitably encounter difficulties associated with their interactions with blood components. For example, it is known that cationic nanoparticles attract opsonizing proteins. That causes rapid plasma clearance of the nanocarriers leading to short nanoparticle plasma half-life [102]. Therefore, it is necessary to study in detail the issues related to the factors that affect blood circulation [8,103], as well as elimination [104,105] of nanoparticles for successful applications of in vivo magnetofection, search for new hybrid delivering nanomaterials [106-109] or implementation of more efficient biochemical binding and targeting techniques [110-116]. However, we believe that the magnetofection technique can become a solid option for in vivo targeting combined with improved efficacy of gene delivery, potentially in combination with other physical techniques (electroporation, sonoporation) if appropriate magnetic fields can be generated and if an ideal coating of magnetic particles is found. Still, many questions and problems remain to be addressed before it becomes an efficient and optimized clinical tool for gene therapy.

Author Contributions: Writing —original draft preparation, A.A.S.; writing-review and editing, A.A.S. and P.I.N.; supervision and project administration, M.P.N. All authors have read and agreed to the published version of the manuscript.

Funding: The research was supported by the Ministry of Science and Higher Education of the Russian Federation, contract for the organization and development of world-class research centers No. 075-15-2020-912.

Data Availability Statement: Not applicable.

Conflicts of Interest: The authors declare no conflict of interest.

\section{References}

1. Plank, C.; Zelphati, O.; Mykhaylyk, O. Magnetically enhanced nucleic acid delivery. Ten years of magnetofection-Progress and prospects. Adv. Drug Deliv. Rev. 2011, 63, 1300-1331. [CrossRef]

2. Kawakami, S.; Higuchi, Y.; Hashida, M. Nonviral approaches for targeted delivery of plasmid DNA and oligonucleotide. J. Pharm. Sci. 2008, 97, 726-745. [CrossRef]

3. Luo, D.; Saltzman, W.M. Enhancement of transfection by physical concentration of DNA at the cell surface. Nat. Biotechnol. 2000, 18, 893-895. [CrossRef]

4. Pershina, A.G.; Sazonov, A.E.; Filimonov, V.D. Magnetic nanoparticles-DNA interactions: Design and applications of nanobiohybrid systems. Russ. Chem. Rev. 2014, 83, 299-322. [CrossRef]

5. Sosa-Acosta, J.R.; Iriarte-Mesa, C.; Ortega, G.A.; Díaz-García, A.M. DNA-Iron Oxide Nanoparticles Conjugates: Functional Magnetic Nanoplatforms in Biomedical Applications. Top. Curr. Chem. 2020, 378, 1-29. [CrossRef]

6. Tregubov, A.A.; Nikitin, P.I.; Nikitin, M.P. Advanced Smart Nanomaterials with Integrated Logic-Gating and Biocomputing: Dawn of Theranostic Nanorobots. Chem. Rev. 2018, 118, 10294-10348. [CrossRef]

7. Nikitin, M.P.; Shipunova, V.; Deyev, S.; Nikitin, P.I. Biocomputing based on particle disassembly. Nat. Nanotechnol. 2014, 9, 716-722. [CrossRef]

8. Nikitin, M.P.; Zelepukin, I.; Shipunova, V.O.; Sokolov, I.L.; Deyev, S.M.; Nikitin, P.I. Enhancement of the blood-circulation time and performance of nanomedicines via the forced clearance of erythrocytes. Nat. Biomed. Eng. 2020, 4, 717-731. [CrossRef]

9. Morozov, V.N.; Kanev, I.L.; Mikheev, A.Y.; Shlyapnikova, E.A.; Shlyapnikov, Y.M.; Nikitin, M.P.; Nikitin, P.; Nwabueze, A.O.; van Hoek, M. Generation and delivery of nanoaerosols from biological and biologically active substances. J. Aerosol Sci. 2014, 69, 48-61. [CrossRef]

10. Namiki, Y.; Namiki, T.; Yoshida, H.; Ishii, Y.; Tsubota, A.; Koido, S.; Nariai, K.; Mitsunaga, M.; Yanagisawa, S.; Kashiwagi, H.; et al. A novel magnetic crystal-lipid nanostructure for magnetically guided in vivo gene delivery. Nat. Nanotechnol. 2009, 4, 598-606. [CrossRef] 
11. Cho, Y.-S.; Yoon, T.-J.; Jang, E.-S.; Hong, K.S.; Lee, S.Y.; Kim, O.R.; Park, C.; Kim, Y.-J.; Yi, G.-C.; Chang, K. Cetuximab-conjugated magneto-fluorescent silica nanoparticles for in vivo colon cancer targeting and imaging. Cancer Lett. 2010, 299, 63-71. [CrossRef]

12. Tregubov, A.; Sokolov, I.; Babenyshev, A.; Nikitin, P.; Cherkasov, V.; Nikitin, M. Magnetic hybrid magnetite/metal organic framework nanoparticles: Facile preparation, post-synthetic biofunctionalization and tracking in vivo with magnetic methods. J. Magn. Magn. Mater. 2018, 449, 590-596. [CrossRef]

13. Motiei, M.; Dreifuss, T.; Sadan, T.; Omer, N.; Blumenfeld-Katzir, T.; Fragogeorgi, E.; Loudos, G.; Popovtzer, R.; Ben-Eliezer, N. Trimodal Nanoparticle Contrast Agent for CT, MRI and SPECT Imaging: Synthesis and Characterization of Radiolabeled Core/Shell Iron Oxide@Gold Nanoparticles. Chem. Lett. 2019, 48, 291-294. [CrossRef]

14. Lepeltier, E.; Rijo, P.; Rizzolio, F.; Popovtzer, R.; Petrikaite, V.; Assaraf, Y.G.; Passirani, C. Nanomedicine to target multidrug resistant tumors. Drug Resist. Updat. 2020, 52, 100704. [CrossRef]

15. Medarova, Z.; Pham, W.; Farrar, C.; Petkova, V.; Moore, A.M. In vivo imaging of siRNA delivery and silencing in tumors. Nat. Med. 2007, 13, 372-377. [CrossRef]

16. Kumar, M.; Yigit, M.; Dai, G.; Moore, A.; Medarova, Z. Image-Guided Breast Tumor Therapy Using a Small Interfering RNA Nanodrug. Cancer Res. 2010, 70, 7553-7561. [CrossRef]

17. Znoyko, S.L.; Orlov, A.; Pushkarev, A.V.; Mochalova, E.N.; Guteneva, N.V.; Lunin, A.; Nikitin, M.P.; Nikitin, P.I. Ultrasensitive quantitative detection of small molecules with rapid lateral-flow assay based on high-affinity bifunctional ligand and magnetic nanolabels. Anal. Chim. Acta 2018, 1034, 161-167. [CrossRef]

18. Guteneva, N.V.; Znoyko, S.L.; Orlov, A.V.; Nikitin, M.P.; Nikitin, P.I. Rapid lateral flow assays based on the quantification of magnetic nanoparticle labels for multiplexed immunodetection of small molecules: Application to the determination of drugs of abuse. Microchim. Acta 2019, 186, 1-9. [CrossRef]

19. Bragina, V.A.; Orlov, A.V.; Znoyko, S.L.; Pushkarev, A.V.; Novichikhin, D.O.; Guteneva, N.V.; Nikitin, M.P.; Gorshkov, B.G.; Nikitin, P.I. Nanobiosensing based on optically selected antibodies and superparamagnetic labels for rapid and highly sensitive quantification of polyvalent hepatitis B surface antigen. Anal. Methods 2021, 13, 2424-2433. [CrossRef]

20. Nikitin, M.P.; Vetoshko, P.M.; Brusentsov, N.A.; Nikitin, P.I. Highly sensitive room-temperature method of non-invasive in vivo detection of magnetic nanoparticles. J. Magn. Magn. Mater. 2009, 321, 1658-1661. [CrossRef]

21. Nikitin, M.P.; Orlov, A.V.; Sokolov, I.L.; Minakov, A.A.; Nikitin, P.I.; Ding, J.; Bader, S.D.; Rozhkova, E.A.; Novosad, V. Ultrasensitive detection enabled by nonlinear magnetization of nanomagnetic labels. Nanoscale 2018, 10, 11642-11650. [CrossRef]

22. Safarik, I.; Safarikova, M. BioMagnetic Research and Technology: A new online journal. Biomagn. Res. Technol. 2003, 1, 1. [CrossRef]

23. Haimov-Talmoud, E.; Harel, Y.; Schori, H.; Motiei, M.; Atkins, A.; Popovtzer, R.; Lellouche, J.-P.; Shefi, O. Magnetic Targeting of mTHPC To Improve the Selectivity and Efficiency of Photodynamic Therapy. ACS Appl. Mater. Interfaces 2019, 11, 45368-45380. [CrossRef]

24. Berry, C.C.; Curtis, A.S.G. Functionalisation of magnetic nanoparticles for applications in biomedicine. J. Phys. D Appl. Phys. 2003, 36, R198-R206. [CrossRef]

25. Jiang, S.; Eltoukhy, A.A.; Love, K.T.; Langer, R.; Anderson, D.G. Lipidoid-Coated Iron Oxide Nanoparticles for Efficient DNA and siRNA delivery. Nano Lett. 2013, 13, 1059-1064. [CrossRef]

26. Zhang, L.; Wang, T.; Li, L.; Wang, C.; Su, Z.; Li, J. Multifunctional fluorescent-magnetic polyethyleneimine functionalized Fe3O4-mesoporous silica yolk-shell nanocapsules for siRNA delivery. Chem. Commun. 2012, 48, 8706-8708. [CrossRef]

27. Mykhaylyk, O.; Antequera, Y.S.; Vlaskou, D.; Plank, C. Generation of magnetic nonviral gene transfer agents and magnetofection in vitro. Nat. Protoc. 2007, 2, 2391-2411. [CrossRef]

28. Plank, C.; Anton, M.; Rudolph, C.; Rosenecker, J.; Krötz, F. Enhancing and targeting nucleic acid delivery by magnetic force. Expert Opin. Biol. Ther. 2003, 3, 745-758. [CrossRef]

29. Boussif, O.; Lezoualc'H, F.; Zanta, M.A.; Mergny, M.D.; Scherman, D.; Demeneix, B.; Behr, J.P. A versatile vector for gene and oligonucleotide transfer into cells in culture and in vivo: Polyethylenimine. Proc. Natl. Acad. Sci. USA 1995, 92, 7297-7301. [CrossRef]

30. Sauer, A.; de Bruin, K.; Ruthardt, N.; Mykhaylyk, O.; Plank, C.; Bräuchle, C. Dynamics of magnetic lipoplexes studied by single particle tracking in living cells. J. Control. Release 2009, 137, 136-145. [CrossRef]

31. de Bruin, K.; Ruthardt, N.; von Gersdorff, K.; Bausinger, R.; Wagner, E.; Ogris, M.; Bräuchle, C. Cellular Dynamics of EGF Receptor-Targeted Synthetic Viruses. Mol. Ther. 2007, 15, 1297-1305. [CrossRef]

32. Song, H.P.; Yang, J.Y.; Lo, S.L.; Wang, Y.; Fan, W.M.; Tang, X.S.; Xue, J.M.; Wang, S. Gene transfer using self-assembled ternary complexes of cationic magnetic nanoparticles, plasmid DNA and cell-penetrating Tat peptide. Biomaterials. 2010, 31, 769-778. [CrossRef]

33. Plank, C.; Rosenecker, J. Magnetofection: The Use of Magnetic Nanoparticles for Nucleic Acid Delivery. Cold Spring Harb. Protoc. 2009, 2009, pdb-prot5230. [CrossRef]

34. Castellani, S.; Orlando, C.; Carbone, A.; Di Gioia, S.; Conese, M. Magnetofection Enhances Lentiviral-Mediated Transduction of Airway Epithelial Cells through Extracellular and Cellular Barriers. Genes 2016, 7, 103. [CrossRef]

35. Plank, C.; Schillinger, U.; Scherer, F.; Bergemann, C.; Remy, J.-S.; Krötz, F.; Anton, M.; Lausier, J.; Rosenecker, J. The Magnetofection Method: Using Magnetic Force to Enhance Gene Delivery. Biol. Chem. 2003, 384, 737-747. [CrossRef]

36. Schillinger, U.; Brill, T.; Rudolph, C.; Huth, S.; Gersting, S.; Krötz, F.; Hirschberger, J.; Bergemann, C.; Plank, C. Advances in magnetofection-magnetically guided nucleic acid delivery. J. Magn. Magn. Mater. 2005, 293, 501-508. [CrossRef] 
37. Schwerdt, J.I.; Goya, G.F.; Calatayud, M.P.; Herenu, C.B.; Reggiani, P.C.; Goya, R.G. Magnetic field-assisted gene delivery: Achievements and therapeutic potential. Curr. Gene Ther. 2012, 12, 116-126. [CrossRef]

38. Laurent, N.; Sapet, C.; Le Gourrierec, L.; Bertosio, E.; Zelphati, O. Nucleic acid delivery using magnetic nanoparticles: The Magnetofection ${ }^{\mathrm{TM}}$ technology. Ther. Deliv. 2011, 2, 471-482. [CrossRef]

39. Dobson, J.M. Gene therapy progress and prospects: Magnetic nanoparticle-based gene delivery. Gene Ther. 2006, 13, 283-287. [CrossRef]

40. Sicard, F.; Sapet, C.; Laurent, N.; Bertosio, E.; Bertuzzi, M.; Zelphati, O. Magnetofection of Minicircle DNA Vectors. In Minicircle and Miniplasmid DNA Vectors; Wiley: Hoboken, NJ, USA, 2013; pp. 165-176.

41. Kami, D.; Takeda, S.; Itakura, Y.; Gojo, S.; Watanabe, M.; Toyoda, M. Application of Magnetic Nanoparticles to Gene Delivery. Int. J. Mol. Sci. 2011, 12, 3705-3722. [CrossRef]

42. Sizikov, A.; Kharlamova, M.; Nikitin, M.; Nikitin, P.; Kolychev, E. Nonviral Locally Injected Magnetic Vectors for In Vivo Gene Delivery: A Review of Studies on Magnetofection. Nanomaterials 2021, 11, 1078. [CrossRef]

43. Zhang, T.; Xu, Q.; Huang, T.; Ling, D.; Gao, J. New Insights into Biocompatible Iron Oxide Nanoparticles: A Potential Booster of Gene Delivery to Stem Cells. Small 2020, 16, 2001588. [CrossRef]

44. Wang, C.; Ding, C.; Kong, M.; Dong, A.; Qian, J.; Jiang, D.; Shen, Z. Tumor-targeting magnetic lipoplex delivery of short hairpin RNA suppresses IGF-1R overexpression of lung adenocarcinoma A549 cells in vitro and in vivo. Biochem. Biophys. Res. Commun. 2011, 410, 537-542. [CrossRef]

45. Kong, M.; Li, X.; Wang, C.; Dong, A.; Duan, Q.; Shen, Z.; Ding, C. Tissue distribution and cancer growth inhibition of magnetic lipoplex-delivered type 1 insulin-like growth factor receptor shRNA in nude mice. Acta Biochim. Biophys. Sin. 2012, 44, 591-596. [CrossRef]

46. Xu, Y.; Li, X.; Kong, M.; Jiang, D.; Dong, A.; Shen, Z.; Duan, Q. Cardiac-targeting magnetic lipoplex delivery of SH-IGF1R plasmid attenuate norepinephrine-induced cardiac hypertrophy in murine heart. Biosci. Rep. 2014, 34, 575-582. [CrossRef]

47. Xie, L.; Jiang, Q.; He, Y.; Nie, Y.; Yue, D.; Gu, Z. Insight into the efficient transfection activity of a designed low aggregated magnetic polyethyleneimine/DNA complex in serum-containing medium and the application in vivo. Biomater. Sci. 2015, 3, 446-456. [CrossRef]

48. Li, W.; Ma, N.; Ong, L.-L.; Kaminski, A.; Skrabal, C.; Ugurlucan, M.; Lorenz, P.; Gatzen, H.-H.; Lützow, K.; Lendlein, A.; et al. Enhanced thoracic gene delivery by magnetic nanobead-mediated vector. J. Gene Med. 2008, 10, 897-909. [CrossRef]

49. Krötz, F.; de Wit, C.; Sohn, H.-Y.; Zahler, S.; Gloe, T.; Pohl, U.; Plank, C. Magnetofection-A highly efficient tool for antisense oligonucleotide delivery in vitro and in vivo. Mol. Ther. 2003, 7, 700-710. [CrossRef]

50. Zheng, X.; Lu, J.; Deng, L.; Xiong, Y.; Chen, J. Preparation and characterization of magnetic cationic liposome in gene delivery. Int. J. Pharm. 2009, 366, 211-217. [CrossRef]

51. Lo, Y.-L.; Chou, H.-L.; Liao, Z.-X.; Huang, S.-J.; Ke, J.-H.; Liu, Y.-S.; Chiu, C.-C.; Wang, L.-F. Chondroitin sulfate-polyethylenimine copolymer-coated superparamagnetic iron oxide nanoparticles as an efficient magneto-gene carrier for microRNA-encoding plasmid DNA delivery. Nanoscale 2015, 7, 8554-8565. [CrossRef]

52. Liu, D.-Z.; Cheng, Y.; Cai, R.-Q.; Wang, B.W.-W.; Cui, H.; Liu, M.; Zhang, B.-L.; Mei, Q.-B.; Zhou, S.-Y. The enhancement of siPLK1 penetration across BBB and its anti glioblastoma activity in vivo by magnet and transferrin co-modified nanoparticle. Nanomed. Nanotechnol. Biol. Med. 2018, 14, 991-1003. [CrossRef]

53. Shan, X.-Y.; Xu, T.-T.; Liu, Z.-L.; Shu-Zhong, G.; Zhang, Y.-D.; Guo, S.-Z.; Wang, B. Targeting of angiopoietin 2-small interfering RNA plasmid/chitosan magnetic nanoparticles in a mouse model of malignant melanoma in vivo. Oncol. Lett. 2017, 14, 2320-2324. [CrossRef]

54. Wang, Z.; Chang, Z.; Lu, M.; Shao, D.; Yue, J.; Yang, D.; Zheng, X.; Li, M.; He, K.; Zhang, M.; et al. Shape-controlled magnetic mesoporous silica nanoparticles for magnetically-mediated suicide gene therapy of hepatocellular carcinoma. Biomaterials 2018, 154, 147-157. [CrossRef]

55. Xue, W.-J.; Feng, Y.; Wang, F.; Guo, Y.-B.; Li, P.; Wang, L.; Liu, Y.-F.; Wang, Z.-W.; Yang, Y.-M.; Mao, Q.-S. Asialoglycoprotein receptor-magnetic dual targeting nanoparticles for delivery of RASSF1A to hepatocellular carcinoma. Sci. Rep. 2016, 6, 22149. [CrossRef]

56. Yang, Z.; Duan, J.; Wang, J.; Liu, Q.; Shang, R.; Yang, X.; Lu, P.; Xia, C.; Wang, L.; Dou, K. Superparamagnetic iron oxide nanoparticles modified with polyethylenimine and galactose for siRNA targeted delivery in hepatocellular carcinoma therapy. Int. J. Nanomed. 2018, 13, 1851-1865. [CrossRef]

57. Li, W.; Nesselmann, C.; Zhou, Z.; Ong, L.-L.; Öri, F.; Tang, G.; Kaminski, A.; Lützow, K.; Lendlein, A.; Liebold, A.; et al. Gene delivery to the heart by magnetic nanobeads. J. Magn. Magn. Mater. 2007, 311, 336-341. [CrossRef]

58. Peng, Z.; Wang, C.; Fang, E.; Lu, X.; Wang, G.; Tong, Q. Co-Delivery of Doxorubicin and SATB1 shRNA by Thermosensitive Magnetic Cationic Liposomes for Gastric Cancer Therapy. PLoS ONE 2014, 9, e92924. [CrossRef]

59. Mannell, H.; Pircher, J.; Fochler, F.; Stampnik, Y.; Räthel, T.; Gleich, B.; Plank, C.; Mykhaylyk, O.; Dahmani, C.; Wörnle, M.; et al. Site directed vascular gene delivery in vivo by ultrasonic destruction of magnetic nanoparticle coated microbubbles. Nanomed. Nanotechnol. Biol. Med. 2012, 8, 1309-1318. [CrossRef]

60. Xie, L.; Jiang, W.; Nie, Y.; He, Y.; Jiang, Q.; Lan, F.; Wu, Y.; Gu, Z. Low aggregation magnetic polyethyleneimine complexes with different saturation magnetization for efficient gene transfection in vitro and in vivo. RSC Adv. 2013, 3, 23571-23581. [CrossRef] 
61. Sun, S.; Zeng, H.; Robinson, D.B.; Raoux, S.; Rice, P.M.; Wang, S.X.; Li, G. Monodisperse $\mathrm{MFe}_{2} \mathrm{O}_{4}(\mathrm{M}=\mathrm{Fe}, \mathrm{Co}, \mathrm{Mn}) \mathrm{Nanoparticles.}$ J. Am. Chem. Soc. 2004, 126, 273-279. [CrossRef]

62. Lu, Z.; Dai, J.; Song, X.; Wang, G.; Yang, W. Facile synthesis of Fe3O4/SiO2 composite nanoparticles from primary silica particles. Colloids Surf. A Physicochem. Eng. Asp. 2008, 317, 450-456. [CrossRef]

63. Ge, J.; Hu, Y.; Biasini, M.; Dong, C.; Guo, J.; Beyermann, W.P.; Yin, Y. One-Step Synthesis of Highly Water-Soluble Magnetite Colloidal Nanocrystals. Chem.-A Eur. J. 2007, 13, 7153-7161. [CrossRef]

64. Matsumura, Y.; Maeda, H. A New Concept for Macromolecular Therapeutics in Cancer Chemotherapy: Mechanism of Tumoritropic Accumulation of Proteins and the Antitumor Agent Smancs. Cancer Res. 1986, 46, 6387-6392.

65. Xia, H.; Zhang, L.; Chen, Q.-D.; Guo, L.; Fang, H.-H.; Li, X.-B.; Song, J.-F.; Huang, X.-R.; Sun, H.-B. Band-Gap-Controllable Photonic Crystals Consisting of Magnetic Nanocrystal Clusters in a Solidified Polymer Matrix. J. Phys. Chem. C 2009, 113, 18542-18545. [CrossRef]

66. Shao, D.; Wang, Z.; Dong, W.-F.; Zhang, X.; Zheng, X.; Xiao, X.-A.; Wang, Y.-S.; Zhao, X.; Zhang, M.; Li, J.; et al. Facile Synthesis of Core-shell Magnetic Mesoporous Silica Nanoparticles for pH-sensitive Anticancer Drug Delivery. Chem. Biol. Drug Des. 2015, 86, 1548-1553. [CrossRef] [PubMed]

67. Zhang, L.; Zhang, F.; Dong, W.-F.; Song, J.-F.; Huo, Q.-S.; Sun, H.-B. Magnetic-mesoporous Janus nanoparticles. Chem. Commun. 2011, 47, 1225-1227. [CrossRef]

68. Shao, D.; Zhang, X.; Liu, W.; Zhang, F.; Zheng, X.; Qiao, P.; Li, J.; Dong, W.-F.; Chen, L. Janus Silver-Mesoporous Silica Nanocarriers for SERS Traceable and pH-Sensitive Drug Delivery in Cancer Therapy. ACS Appl. Mater. Interfaces 2016, 8, 4303-4308. [CrossRef]

69. Wang, Z.; Wang, Y.-S.; Chang, Z.-M.; Li, L.; Zhang, Y.; Lu, M.-M.; Zheng, X.; Li, M.; Shao, D.; Li, J.; et al. Berberine-loaded Janus nanocarriers for magnetic field-enhanced therapy against hepatocellular carcinoma. Chem. Biol. Drug Des. 2016, 89, 464-469. [CrossRef]

70. Shao, D.; Zeng, Q.; Fan, Z.; Li, J.; Zhang, M.; Zhang, Y.; Li, O.; Chen, L.; Kong, X.; Zhang, H. Monitoring HSV-TK/ganciclovir cancer suicide gene therapy using CdTe/CdS core/shell quantum dots. Biomaterials 2012, 33, 4336-4344. [CrossRef]

71. Shao, D.; Li, J.; Xiao, X.; Zhang, M.; Pan, Y.; Li, S.; Wang, Z.; Zhang, X.; Zheng, H.; Zhang, X.; et al. Real-Time Visualizing and Tracing of HSV-TK/GCV Suicide Gene Therapy by Near-Infrared Fluorescent Quantum Dots. ACS Appl. Mater. Interfaces 2014, 6, 11082-11090. [CrossRef]

72. Liu, C.; Zhang, L.; Zhu, W.; Guo, R.; Sun, H.; Chen, X.; Deng, N. Barriers and Strategies of Cationic Liposomes for Cancer Gene Therapy. Mol. Ther.-Methods Clin. Dev. 2020, 18, 751-764. [CrossRef] [PubMed]

73. Beltrán-Gracia, E.; López-Camacho, A.; Higuera-Ciapara, I.; Velázquez-Fernández, J.B.; Vallejo-Cardona, A.A. Nanomedicine review: Clinical developments in liposomal applications. Cancer Nanotechnol. 2019, 10, 1-40. [CrossRef]

74. Bulbake, U.; Doppalapudi, S.; Kommineni, N.; Khan, W. Liposomal Formulations in Clinical Use: An Updated Review. Pharmaceutics 2017, 9, 12. [CrossRef] [PubMed]

75. Holzbach, T.; Vlaskou, D.; Neshkova, I.; Konerding, M.A.; Wörtler, K.; Mykhaylyk, O.; Gänsbacher, B.; Machens, H.; Plank, C.; Giunta, R.E. Non-viral VEGF165 gene therapy-Magnetofection of acoustically active magnetic lipospheres ('magnetobubbles') increases tissue survival in an oversized skin flap model. J. Cell. Mol. Med. 2008, 14, 587-599. [CrossRef]

76. Crichton, R.R.; Charloteaux-Wauters, M. Iron transport and storage. JBIC J. Biol. Inorg. Chem. 1987, 164, 485-506. [CrossRef]

77. Miao, L.; Zhang, K.; Qiao, C.; Jin, X.; Zheng, C.; Yang, B.; Sun, H. Antitumor effect of human TRAIL on adenoid cystic carcinoma using magnetic nanoparticle-mediated gene expression. Nanomed. Nanotechnol. Biol. Med. 2013, 9, 141-150. [CrossRef]

78. Sato, A.; Takagi, M.; Shimamoto, A.; Kawakami, S.; Hashida, M. Small interfering RNA delivery to the liver by intravenous administration of galactosylated cationic liposomes in mice. Biomaterials 2007, 28, 1434-1442. [CrossRef] [PubMed]

79. Kou, G.; Wang, S.; Cheng, C.; Gao, J.; Li, B.; Wang, H.; Qian, W.; Hou, S.; Zhang, D.; Dai, J.; et al. Development of SM5-1conjugated ultrasmall superparamagnetic iron oxide nanoparticles for hepatoma detection. Biochem. Biophys. Res. Commun. 2008, 374, 192-197. [CrossRef]

80. Bromberg, L.; Diao, Y.; Wu, H.; Speakman, S.A.; Hatton, T.A. Chromium(III) Terephthalate Metal Organic Framework (MIL-101): HF-Free Synthesis, Structure, Polyoxometalate Composites, and Catalytic Properties. Chem. Mater. 2012, 24, 1664-1675. [CrossRef]

81. A Furge, K.; Zhang, Y.-W.; Woude, G.F.V. Met receptor tyrosine kinase: Enhanced signaling through adapter proteins. Oncogene 2000, 19, 5582-5589. [CrossRef]

82. Amirfazli, A. Magnetic nanoparticles hit the target. Nat. Nanotechnol. 2007, 2, 467-468. [CrossRef] [PubMed]

83. Dempsey, N.M.; Le Roy, D.; Marelli-Mathevon, H.; Shaw, G.; Dias, A.; Kramer, R.B.G.; Cuong, L.V.; Kustov, M.; Zanini, L.F.; Villard, C.; et al. Micro-magnetic imprinting of high field gradient magnetic flux sources. Appl. Phys. Lett. 2014, 104, 262401. [CrossRef]

84. Huang, W.; Liu, Z.; Zhou, G.; Ling, J.; Tian, A.; Sun, N. Silencing Bag-1 gene via magnetic gold nanoparticle-delivered siRNA plasmid for colorectal cancer therapy in vivo and in vitro. Tumor Biol. 2016, 37, 10365-10374. [CrossRef] [PubMed]

85. Polyak, B.; Fishbein, I.; Chorny, M.; Alferiev, I.; Williams, D.; Yellen, B.; Friedman, G.; Levy, R.J. High field gradient targeting of magnetic nanoparticle-loaded endothelial cells to the surfaces of steel stents. Proc. Natl. Acad. Sci. USA 2008, 105, 698-703. [CrossRef] [PubMed]

86. Pislaru, S.V.; Harbuzariu, A.; Gulati, R.; Witt, T.; Sandhu, N.P.; Simari, R.D.; Sandhu, G.S. Magnetically Targeted Endothelial Cell Localization in Stented Vessels. J. Am. Coll. Cardiol. 2006, 48, 1839-1845. [CrossRef] 
87. Chorny, M.; Fishbein, I.; Yellen, B.B.; Alferiev, I.S.; Bakay, M.; Ganta, S.; Adamo, R.; Amiji, M.; Friedman, G.; Levy, R.J. Targeting stents with local delivery of paclitaxel-loaded magnetic nanoparticles using uniform fields. Proc. Natl. Acad. Sci. USA 2010, 107, 8346-8351. [CrossRef]

88. Räthel, T.; Mannell, H.; Pircher, J.; Gleich, B.; Pohl, U.; Krötz, F. Magnetic Stents Retain Nanoparticle-Bound Antirestenotic Drugs Transported by Lipid Microbubbles. Pharm. Res. 2011, 29, 1295-1307. [CrossRef]

89. Babincová, M.; Babinec, P.; Bergemann, C. High-Gradient Magnetic Capture of Ferrofluids: Implications for Drug Targeting and Tumor Embolization. Zeitschrift Naturforschung C 2001, 56, 909-911. [CrossRef]

90. Yellen, B.B.; Forbes, Z.G.; Halverson, D.S.; Fridman, G.; Barbee, K.A.; Chorny, M.; Levy, R.; Friedman, G. Targeted drug delivery to magnetic implants for therapeutic applications. J. Magn. Magn. Mater. 2005, 293, 647-654. [CrossRef]

91. Alexiou, C.; Diehl, D.; Henninger, P.; Iro, H.; Rockelein, R.; Schmidt, W.; Weber, H. A High Field Gradient Magnet for Magnetic Drug Targeting. IEEE Trans. Appl. Supercond. 2006, 16, 1527-1530. [CrossRef]

92. McBain, S.C.; Griesenbach, U.; Xenariou, S.; Keramane, A.; Batich, C.D.; Alton, E.W.F.W.; Dobson, J. Magnetic nanoparticles as gene delivery agents: Enhanced transfection in the presence of oscillating magnet arrays. Nanotechnology 2008, 19, 405102. [CrossRef] [PubMed]

93. Kamau, S.W. Enhancement of the efficiency of non-viral gene delivery by application of pulsed magnetic field. Nucleic Acids Res. 2006, 34, e40. [CrossRef] [PubMed]

94. Pickard, M.; Chari, D. Enhancement of magnetic nanoparticle-mediated gene transfer to astrocytes by 'magnetofection': Effects of static and oscillating fields. Nanomedicine 2010, 5, 217-232. [CrossRef] [PubMed]

95. Blümler, P. Magnetic Guiding with Permanent Magnets: Concept, Realization and Applications to Nanoparticles and Cells. Cells 2021, 10, 2708. [CrossRef]

96. Shapiro, B.; Kulkarni, S.; Nacev, A.; Muro, S.; Stepanov, P.Y.; Weinberg, I.N. Open challenges in magnetic drug targeting. Wiley Interdiscip. Rev. Nanomed. Nanobiotechnol. 2015, 7, 446-457. [CrossRef]

97. Liu, Y.-L.; Chen, D.; Shang, P.; Yin, D.-C. A review of magnet systems for targeted drug delivery. J. Control. Release 2019, 302, 90-104. [CrossRef]

98. Pilapong, C.; Sitthichai, S.; Thongtem, S.; Thongtem, T. Smart magnetic nanoparticle-aptamer probe for targeted imaging and treatment of hepatocellular carcinoma. Int. J. Pharm. 2014, 473, 469-474. [CrossRef]

99. Logeart, D.; Hatem, S.; Heimburger, M.; Le Roux, A.; Michel, J.-B.; Mercadier, J.-J. How to Optimize In Vivo Gene Transfer to Cardiac Myocytes: Mechanical or Pharmacological Procedures? Hum. Gene Ther. 2001, 12, 1601-1610. [CrossRef]

100. Gregorevic, P.; Blankinship, M.J.; Allen, J.M.; Crawford, R.W.; Meuse, L.; Miller, D.; Russell, D.W.; Chamberlain, J. Systemic delivery of genes to striated muscles using adeno-associated viral vectors. Nat. Med. 2004, 10, 828-834. [CrossRef]

101. Donahue, J.K.; Kikkawa, K.; Thomas, A.D.; Marban, E.; Lawrence, J.H. Acceleration of widespread adenoviral gene transfer to intact rabbit hearts by coronary perfusion with low calcium and serotonin. Gene Ther. 1998, 5, 630-634. [CrossRef]

102. Weissleder, R.; Bogdanov, A.; Neuwelt, E.A.; Papisov, M. Long-circulating iron oxides for MR imaging. Adv. Drug Deliv. Rev. 1995, 16, 321-334. [CrossRef]

103. Mirkasymov, A.B.; Zelepukin, I.V.; Nikitin, P.I.; Nikitin, M.P.; Deyev, S.M. In vivo blockade of mononuclear phagocyte system with solid nanoparticles: Efficiency and affecting factors. J. Control. Release 2021, 330, 111-118. [CrossRef] [PubMed]

104. Zelepukin, I.V.; Yaremenko, A.V.; Yuryev, M.V.; Mirkasymov, A.B.; Sokolov, I.L.; Deyev, S.M.; Nikitin, P.I.; Nikitin, M.P. Fast processes of nanoparticle blood clearance: Comprehensive study. J. Control. Release 2020, 326, 181-191. [CrossRef] [PubMed]

105. Zelepukin, I.V.; Yaremenko, A.V.; Ivanov, I.N.; Yuryev, M.V.; Cherkasov, V.R.; Deyev, S.M.; Nikitin, P.I.; Nikitin, M.P. Long-Term Fate of Magnetic Particles in Mice: A Comprehensive Study. ACS Nano 2021. [CrossRef] [PubMed]

106. Mukherjee, A.; Waters, A.K.; Kalyan, P.; Achrol, A.S.; Kesari, S.; Yenugonda, V.M. Lipid-polymer hybrid nanoparticles as a next-generation drug delivery platform: State of the art, emerging technologies, and perspectives. Int. J. Nanomed. 2019, ume 14, 1937-1952. [CrossRef]

107. Zelepukin, I.V.; Yaremenko, A.V.; Shipunova, V.O.; Babenyshev, A.V.; Balalaeva, I.V.; Nikitin, P.I.; Deyev, S.M.; Nikitin, M.P. Nanoparticle-based drug delivery via RBC-hitchhiking for the inhibition of lung metastases growth. Nanoscale 2019, 11, 1636-1646. [CrossRef]

108. Ringaci, A.; Yaremenko, A.; Shevchenko, K.; Zvereva, S.; Nikitin, M. Metal-organic frameworks for simultaneous gene and small molecule delivery in vitro and in vivo. Chem. Eng. J. 2021, 418, 129386. [CrossRef]

109. Lunin, A.V.; Korenkov, E.S.; Mochalova, E.N.; Nikitin, M.P. Green Synthesis of Size-Controlled in Vivo Biocompatible Immunoglobulin-Based Nanoparticles by a Swift Thermal Formation. ACS Sustain. Chem. Eng. 2021, 9, 13128-13134. [CrossRef]

110. Morachis, J.M.; Mahmoud, E.A.; Almutairi, A. Physical and Chemical Strategies for Therapeutic Delivery by Using Polymeric Nanoparticles. Pharmacol. Rev. 2012, 64, 505-519. [CrossRef]

111. Cherkasov, V.R.; Mochalova, E.N.; Babenyshev, A.V.; Vasilyeva, A.V.; Nikitin, P.I.; Nikitin, M.P. Nanoparticle Beacons: Supersensitive Smart Materials with On/Off-Switchable Affinity to Biomedical Targets. ACS Nano 2020, 14, 1792-1803. [CrossRef]

112. Polyak, B.; Friedman, G. Magnetic targeting for site-specific drug delivery: Applications and clinical potential. Expert Opin. Drug Deliv. 2009, 6, 53-70. [CrossRef] [PubMed]

113. Orlov, A.; Nikitin, M.P.; Bragina, V.A.; Znoyko, S.L.; Zaikina, M.N.; Ksenevich, T.; Gorshkov, B.G.; Nikitin, P. A new real-time method for investigation of affinity properties and binding kinetics of magnetic nanoparticles. J. Magn. Magn. Mater. 2015, 380, 231-235. [CrossRef] 
114. Chorny, M.; Polyak, B.; Alferiev, I.S.; Walsh, K.; Friedman, G.; Levy, R.J. Magnetically driven plasmid DNA delivery with biodegradable polymeric nanoparticles. FASEB J. 2007, 21, 2510-2519. [CrossRef] [PubMed]

115. Shevchenko, K.G.; Cherkasov, V.R.; Tregubov, A.A.; Nikitin, P.I.; Nikitin, M.P. Surface plasmon resonance as a tool for investigation of non-covalent nanoparticle interactions in heterogeneous self-assembly \& disassembly systems. Biosens. Bioelectron. 2017, 88, 3-8. [CrossRef] [PubMed]

116. Wang, K.; Shang, F.; Chen, D.; Cao, T.; Wang, X.; Jiao, J.; He, S.; Liang, X. Protein liposomes-mediated targeted acetylcholinesterase gene delivery for effective liver cancer therapy. J. Nanobiotechnol. 2021, 19, 1-15. [CrossRef] [PubMed] 